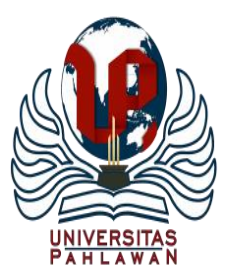

Edukatif : Jurnal Ilmu Pendidikan Volume 3 Nomor 2 Tahun 2021 Halm 523 - 528

EDUKATIF: JURNAL ILMU PENDIDIKAN

Research \& Learning in Education

https://edukatif.org/index.php/edukatif/index

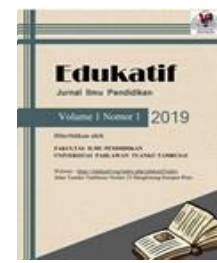

\title{
Urgensi Pendidikan Kewarganegaraan : Reaktualisasi Kapabilitas Berbangsa dan Bernegara pada Siswa Sekolah Dasar
}

\author{
Amala Sundari $^{1 \bowtie}$, Dini Anggraeni Dewi ${ }^{2}$ \\ Universitas Pendidikan Indonesia, Indonesia ${ }^{1,2}$

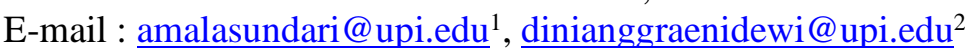

\begin{abstract}
Abstrak
Kesadaran berbangsa dan berengara tentunya merupakan hal yang sangat penting bagi Bangsa Indonesia agar terhindar dari perilaku menyimpang pada masyarakat Indonesia. Penelitian ini bertujuan memberikan gambaran mengenai kemampuan dan membangun kesadaran berbangsa dan bernegara warga negara dan masyarakat khususnya pada generasi pemuda Indonesia yaitu para siswa dan siswi di Sekolah Dasar. Metode penelitian menggunakan pendekatan kualitatif dengan metode studi kasus yang berfokus pada pemahaman terhadap fenomena sosial yang terjadi di masyarakat. Peneliti menggunakan perspektif dari partisipan sebagai gambaran dalam memperoleh hasil penelitian. Informan penitian yaitu siswa Sekolah Dasar Negeri di Kota Bogor yang duduk dibangku kelas tinggi dengan teknik pengumpulan data berupa pengisian formulir quisioner secara online. Hasil penelitian menunjukan bahwa siswa Sekolah Dasar sudah mengetahui dan dapat memahami komponen-komponen dalam hidup berbangsa dan bernegara. Diantarannya menaati norma-norma yang berlaku dalam kehidupan bermasyarakat, berbangsa dan bernegara, melakukan sikap positif terhadap makna dan nilai proklamasi, upaya perlindungan dan penegakan hak asasi manusia dan aktualisasi kemerdekaaan mengemukakan pendapat. Seluruh aspek mulai dari orang tua, masyarakat dan guru perlu ikut serta dalam membangun kesadaran berbangsa dan bernegara pada anak.
\end{abstract}

Kata Kunci: berbangsa dan bernegara, siswa Sekolah Dasar, bermasyarakat.

\begin{abstract}
Having a sense of national awareness is certainly essential for Indonesian to avoid aberrant behavior in Indonesian society. This research aims to describe an idea of the capability to build awareness of citizen and society especially Indonesian youth student's generation and elementary school students. The research used a qualitative approach with case study methods that focus on understanding social phenomena occurring in society. The researchers used the perspective of participants as an illustration in obtaining the results. Research informant was a primary school student in the Bogor city with the data collection techniques of filling up online questionnaires. The research shows that, elementary school students have already knew and understand the components of national life. It adheres to norms applied in society, national life, having a positive attitude toward the meaning and value of the proclamation, the protectification and enforcement of human rights and the attainment of freedom. All aspects ranging from parents, societies and teachers need to participate in building a sense of national awareness of children.
\end{abstract}

Keywords: National awareness, elementary school students, community.

Copyright (c) 2021 Amala Sundari, Dini Anggraeni Dewi

$\triangle$ Corresponding author

Email : amalasundari@upi.edu

DOI : https://doi.org/10.31004/edukatif.v3i2.381

ISSN 2656-8063 (Media Cetak)

ISSN 2656-8071 (Media Online)

Edukatif : Jurnal Ilmu Pendidikan Vol 3 No 2 Tahun 2021

p-ISSN 2656-8063 e-ISSN 2656-8071 
524 Urgensi Pendidikan Kewarganegaraan : Reaktualisasi Kapabilitas Berbangsa dan Bernegara pada Siswa Sekolah Dasar-Amala Sundari, Dini Anggraeni Dewi

DOI: https://doi.org/10.31004/edukatif.v3i2.381

\section{PENDAHULUAN}

Bagian sentral dari sistem pendidikan di Indonesia adalah Pendidikan Kewarganegaraan. Dalam hal itu, proses pendidikan kewarganegaraan direalisasikan dalam kurikulum dan pembelajaran pada seluruh jenjang pendidikan, mulai dari Sekolah Dasar hingga ke Perguruan Tinggi. Fungsi dan perananya dalam rangka pencapaian tujuan pendidikan nasional, pendidikan kewarganegaraan seharusnya dirancang, dikembangkan, dilaksanakan, dan dievaluasi demi terlaksananya tujuan pendidikan nasional. Ketiga hal tersebut merupakan landasan dan kerangka pikir untuk melaksanakan mata kuliah/mata pelajaran pendidikan kewarganegaraan.

Proses pendidikan Kewarganegaraan mampu memberdayakan, membudayakan peserta didik dalam arti bahwa proses dan hasil pendidikan tersebut harus mampu memfasilitasi peserta didik untuk melakukan proses belajar untuk memperluas wawasan (learning to know), belajar untuk membangun kemampuan melakukan sesuatu (learning to do), belajar untuk hidup dan melakuakn kehidupan (learning to be), dan belajar untuk hidup bernegara (learning to live together) (UNESCO, 1996).

Secara konseptual pendidikan kewarganegaraan adalah program pendidikan yang difokuskan pada pengembangan pribadi dan pengembangan individu warga negara secara keseluruhan. Secara psikologis ranah sepantasnya dikembangkan melalui pembelajaran Pendidikan kewarganegaraan (Winataputra, 2003).

Dalam konteks pembangunan bangsa dan karakter (nation and character building) pendidikan kewarganegaraan dalam arti luas memiliki kedudukan, fungsi, dan peran yang sangat penting. Pendidikan kewarganegaraan pada dasarnya merupakan salah satu bentuk pendidikan karakter yang dikembangkan secara sistematis dan sistemik. Dalam konteks itu pendidikan kewarganegaraan tidak bisa dipisahkan dari kerangka kebijakan nasional pembangunan bangsa dan karakter (Akbal, 2016).

Penelitian ini penting dilakukan karena mengingat bahwasanaya kemampuan dalam berbangsa dan bernegara sangatlah fundamental bagi kelangsungan berkehidupan Bangsa Indonesia yang harus ditanamkan dimulai sejak dini pada anak usia sekolah dasar agar tumbuh kesadaran pada generasi muda mengenai pentingnya reaktualisasi sikap berbangsa dan bernegara.

Dalam konteks tersebut pendidikan kewarganegaraan tidak bisa dijauhkan dari kerangka kebijakan nasional pembangunan karakter berbangsa dan bernegara diawali dari memperbaiki kemampuan masyarakat dalam memahami dan menaati hakikat dari norma dan hukum, mengembangkan kemampuan sikap positif terhadap makna dan nilai-nilai catatan panjang proklamasi, kemampuan pada upaya penegakan Hak Asasi Manusia (HAM), juga kemampuan aktualisasi kemerdekaan mengemukakan pendapat di era saat ini.

\section{METODE PENELITIAN}

Penelitian ini menggunakan pendekatan kualitatif dengan metode studi kasus untuk memaknai pehaman siswa sekolah dasar mengenai pengetahuan dan kemampuan kesadaran berbangsa dan bernegara dengan realitas siswa menjalankan kehidupan sehari-hari. Siswa Sekolah Dasar kelas tinggi yang terdapat di Kota Bogor dipilih sebagai target penelitian karena merupakan siswa yang memiliki kedisiplinan kesadaran berbangsa dan bernegara yang tinggi.

Penelitian ini mengambil 15 siswa Sekolah Dasar kelas tinggi secara acak yang terdapat di Kota Bogor sebagai informan dalam proses pengumpulan data. Penelitian ini dilakukan selama 2 minggu, peneliti melakukan observasi dan mengirimkan quisioner secara online melalui google form terhadap informan dalam semua aspek kehidupan berbangsa dan bernegara yang dilaksanakan oleh siswa siswi Sekolah Dasar. Hasil pengumpulan data yang diperoleh kemudian dianalisis menggunakan model skema analisis kualitatif. Data yang berhasil diperoleh kemudian divalidasi menggunakan pengumpulan data. 
525 Urgensi Pendidikan Kewarganegaraan : Reaktualisasi Kapabilitas Berbangsa dan Bernegara pada Siswa Sekolah Dasar-Amala Sundari, Dini Anggraeni Dewi

DOI: https://doi.org/10.31004/edukatif.v3i2.381

\section{HASIL DAN PEMBAHASAN PENELITIAN}

Kesadaran berbangsa dan bernegara merupakan kondisi ketika seorang individu paham secara sadar serta mempunyai rasa tanggungjawab untuk bangsa dan negara yang disebabkan oleh suatu ikatan sebagai warga negara. Kesadaran berbangsa dan benegara merupakan suatu sikap dan tingkah laku yang sesuai dengan kepribadian bangsa dan selalu mengkaitkan dirinya dengan cita-cita dan tujuan hidup bangsanya, tumbuh rasa kesatuan, persatuan bangsa Indonesia, memiliki jiwa besar dan patriotisme serta memiliki kesadaran atas tanggungjawab sebagai warga negara (Rahayu et al., 2019). Kesadaran berbangsa dan bernegara masyarakat Indonesia yang sudah dimulai diajarkan sedari dini berarti seorang warga negara menyadari bahwa ia hidup di dalam sebuah bangsa dan negara yang berasas Bhineka Tunggal Ika atau berbeda-beda namun tetap satu jua. Dengan memiliki rasa sadar warga negara akan menyadari bahwa ia hidup berdampingan dengan masyarakat yang memiliki beragam latar belakang suku, agama, ras, dan golongan sehingga butuh adanya penyesuaian agar dapat menjalin kehidupan secara berdampingan, rukun, dan damai.

Pada penulisan ini menitik beratkan kepada empat aspek penting yang perlu dibahas dalam hal reaktualisasi kapabilitas berbangsa dan bernegara. Karena dirasa hal-hal tersebut sangat urgensi dalam kehidupan berbangsa dan bernegara. Ke empat hal tersebut diantaranya memahami dan menaati hakikat dari norma dan hukum, mengembangkan kemampuan sikap positif terhadap makna dan nilai-nilai catatan panjang proklamasi, kemampuan pada upaya perlindungan dan penegakan Hak Asasi Manusia, juga kemampuan aktualisasi kemerdekaan mengemukakan pendapat di era saat ini.

\section{Menaati Norma-Norma yang Berlaku dalam Kehidupan Bermasyarakat, Berbangsa, dan Bernegara}

Norma lebih dikenal sebagai aturan dalam kehidupan manusia. Sesuai dengan sifatnya, norma perlu dipatuhi setip warga negara yang diberlakukan norma tersebut didalamnya. Secara etimologi, kata norma berasal dari bahasa Belanda, yaitu 'norm' yang artinya patokan, pokok kaidah, atau pedoman. Namun ada yang mengatakan, istilah norma berasal dari bahasa Latin, 'mos" yang artinya kebiasaan, tata kelakuan, ataupun adat istiadat. Sedagkan dalam Kamus Besar Bahasa Indonesia (KBBI) norma merupakan aturan atau ketentuan yang mengikat warga kelompok dalam masyarakat, dipakai sebagai panduan, tatanan, dan pengendali tingkah laku yang sesuai. Norma bisa diartikan juga sebagai ketentuan yang mengatur tingkah dan laku manusia dalam tatanan kehidupan masyarakat.

Dalam kehidupan sehari-hari, semua masyarakat diharapkan untuk tetap menjunjung tinggi nilai norma yang berlaku di tengah-tengah masyarakat. Selain harus menaati norma hukum, kita juga harus menjunjung tinggi norma-norma yang lain, antara lain adalah Nilai norma agama, misalnya dengan menjalankan ajaran agama sebaik-baiknya.

Misalnya, menunaikan salat lima waktu bagi umat muslin atau mengikuti menghadiri ibadah umat Kristiani setiap hari Minggu. Nilai norma kesopanan, seperti berlaku sopan terhadap orangtua, guru, atau teman-teman sebaya, bersikap, berbuat, berbicara, berpakaian, berjalan, makan, minum, hendaknya sesuai dengan norma-norma kesopanan yang berlaku dalam kehidupan sehari-hari di masyarakat dan engamalkan tatakrama atau etika, baik di lingkungan keluarga, sekolah, atau di masyarakat umum. Adapun nilai norma kesusilaan, misalnya orang hendaknya menghindari perbuatan berbohong, menghina orang lain, memfitnah, membuat orang lain malu, menipu, atau melakukan penyimpangan seksual (Nurdiman, 2009).

\section{Sikap Positif Terhadap Makna Dan Nilai-Nilai Proklamasi}

Sejarah perjuangan kemerdekaan bangsa Indonesia, yang berabad panjangnya itu, didorong oleh kondisi penderitaan rakyat, yang jiwa atau semangatnya adalah Pancasila. Perjuangan itu mencapai titik puncaknya ketika Indonesia diproklamasikan. Sebagai warga negara seyogyanya wajib bersyukur kepada Tuhan yang Maha Esa karena telah menjadikan bangsa yang merdeka diatas penjajahan. Sebagai bangsa yang merdeka, 
tentunya kita harus menggunakan hukum-hukum negara yang sudah disepakati bersama. Hukum serta adat colonial bangsa lain harus segera ditinggalkan.

Oleh karena itulah, proklamasi kemerdekaan adalah dasar bagi berlakunya segala sistem peraturan atau ketentuan hukum Indonesia. Proklamasi kemerdekaan Indonesia merupakan norma pertama dari tata hukum baru, yaitu tata hukum Indonesia. Arti Proklamasi bagi bangsa Indonesia adalah Proklamasi berarti pernyataan kebebasan, yaitu kebebasan kembali setelah berababad dibelenggu tangan penjajah, kebebasan dari kekangan dan penindasan bangsa asing, kebebasan dari kehidupan menderita di bawah kekuasaan bangsa lain. Proklamasi berarti kembali menjadi subjek, bukan jadi budak penjajah, dan pelayan bangsa asing. Proklamasi berarti kembali menjadi tuan, yaitu pemilik di rumah sendiri. Bangsa Indonesia dapat mengatur sendiri bangsa, negara dan tanah airnya, tanpa campur tangan bangsa asing. Bangsa Indonesia dapat menyelenggarakan sendiri kepentingan dirinya sendiri dan lagi untuk bangsa yang bukan bangsanya. Hal ini berarti bahwa Indonesia memegang nasibnya dalam tangannya sendiri dan ini berarti pula suatu tanggung jawab. Proklamasi berarti tanggung jawab, yaitu tanggung jawab terhadap bangsa dan tanah air.

Kemerdekaan yang didapatkan oleh Indonesia bukan hasil pemberian, melainkan hasil perjuangan darah para pahlawan yang telah berkorban harta dan jiwa raganya demi bangsa dan negara. Sudah sepantasnya sebagai generasi penerus, kita perlu memahami, menghayati, dan mengamalkan nilai-nilai positif perjuangan para pahlawan. Selain itu, sebagai masyarakat Indonesia juga harus mengamalkan nilai-nilai perjuangan para bapak pendiri bangsa (The Founding Father) dalam merumuskan konstitusi pertama. Nilai-nilai positif perjuangan para pahlawan yang patut teladani oleh masyarakat Indonesia antara lain sebagai sikap cinta tanah air atau patriotisme, dengan selalu memelihara lingkungan hidup dan kerusakan, sikap nasionalisme atau rasa kebangsaan, dengan mengutamakan persatuan dan kesatuan bangsa meskipun dengan kondisi kontur kebudayaan Indonesia yang amat beraneka ragam, sikap tenggang rasa, saling menghargai, dan saling menghormati, misalnya menghargai perbedaan pendapat atau perbedaan keyakinan, sikap bertanggung jawab dan perasaan senasib sepenanggungan dalam mengisi kemerdekaan, mahasiswa sebagai pionir perubahan harus memeberikan pergerakan dalam hal saling berempati dan peduli terhadap sesama manusia, serta sikap pantang menyerah dan tahan penderitaan,sebagai insan yang memiliki akal kita harus selalu berusaha untuk memperbaiki diri dan terus berjuang dalam menjalankan berbagai krusial kehidupan.

\section{Upaya Perlindungan dan Penegakan Hak Asasi Manusia}

Indonesia mengakui dan menjunjung tinggi hak asasi manusia dan kebebasan dasar manusia sebagai hak yang secara kodrati yang melekat dan telah dimiliki pada diri manusia. Hak ini perlu dilindungi, dihormati, dan ditegakkan untuk peningkatan martabat kemanusiaan, kesejahteraan, kebahagiaan, kecerdasan, serta keadilan. Dengan demikian, hak asasi manusia harus terus menjadi titik ukur dan tujuan dalam penyelenggaraan kehidupan bermasyarakat, berbangsa, dan bernegara.

Usaha menegakkan hak asasi manusia yang dilakukan oleh pemerintah dilakukan dengan banyak cara, di antaranya melalui peraturan yang dibuat, penegak hukum atau fasilitas, dan kesadaran hukum masyarakat. Penegakan hak asasi manusia dalam peraturan ada dalam UUD 1945. Selain itu, upaya penegakan hak asasi manusia dilakukan melalui penegakan hukum dan fasilitas. Contohnya adalah memberikan hukuman atau sanksi yang tegas kepada para pelanggar HAM. Selain itu, penegak hukumnya diberikan pembekalan tentang pentingnya hak asasi manusia. Adapun melalui penyediaan fasilitas oleh pemerintah sebagai wadah dalam penegakan hak asasi manusia adalah dengan membentuk berbagai komisi nasional yang menangani tentang hak asasi, seperti Komisi Nasional HAM, Komisi Nasional Perlindungan Anak, Komisi Perempuan, dan Komisi Nasional Anti Kekerasan terhadapPerempuan. Adapun penegakan hak asasi melalui kesadaran masyarakat adalah dengan melakukan pembinaan atau pendidikan kesadaran tentang hak asasi di masyarakat. Salah satunya melalui pendidikan HAM di sekolah dan di luar sekolah. Dalam kehidupan sekolah, sebagai 
siswa tidak boleh membeda-bedakan teman walaupun berbeda keadaannya. Hendaknya dalam bertindak selalu didasarkan atas asas persamaan harkat dan martabat manusia. Tindakan yang dimaksud antara lain memiliki sikap lapang dada, mengutamakan kepentingan orang banyak, menghargai pendapat orang lain, dan menunjukkan sikap tidak memaksakan kehendak atau pendapat kepada orang lain.

\section{Mengemukakan Pendapat}

Perwujudan demokrasi dalam tatanan kehidupan bermasyarakat, berbangsa, dan bernegara salah satunya adalah kemerdekaan mengemukakan pendapat di muka umum. Setiap warga negara berhak mengungkapkan gagasannya dengan secara tertulis ataupun lisan secara bebas dan bertanggung jawab. Menurut UU No. 9 Tahun 1998 tentang Kemerdekaan Menyampaikan Pendapat di Muka Umum, kebebasan berpendapat berkaitan erat dan tidak terpisahkan dari hak untuk berkumpul, memprotes, dan menuntut perubahan.

Hadirnya kebebasan menyampaikan pendapat merupakan bentuk perwujudan demokrasi didalam tatanan kehidupan bermasyarakat, berbangsa, dan bernegara. Kebebasan menyampaikan pendapat ini dijamin oleh UUD 1945. Perbedaan pendapat dan pandangan tidak dilarang, apalagi dilenyapkan, tetapi perlu diatur agar perbedaan yang ada tidak menyebabkan perpecahan sosial di masyarakat.

Dalam melaksanaan kemerdekaan, Pendapat yang diungkapkan di depan umum harus didasarkan pada 4 asas, diantaranya asas keseimbangan antara hak dan kewajiban, asas musyawarah dan mufakat, asas kepastian hukum dan keadilan, serta asas proporsionalitas (keseimbangan). Keempat asas tersebut ialah landasan kebebasan yang bertanggung jawab dalam cara berpikir dan bertindak untuk menyampaikan pendapat di muka umum. Bagi negara demokrasi, perbedaan pendapat adalah hal yang sudah lazim terjadi. Setiap penyampaian pendapat di muka umum dalam berbagai bentuk, yaitu aksi unjuk rasa, pawai, rapat umum, dan mimbar bebas, harus dilaksanakan sesuai dengan ketentuan perundang-undangan.

Hal-hal tersebut diatas selaras dengan penelitian terdahulu yaitu kesadaran bela negara pada mahasiswa diwujudkan dalam bentuk cinta tanah air, kesadaran berbangsa dan bernegara, keyakinan akan kesaktian Pancasila, rela berkorban untuk nusa dan bangsa, dan kemampuan awal bela negara (Rahayu et al., 2019). Namun dalam penilitian yang penulis lakukan disini lebih berfokus kepada empat hal diantaranya memahami dan menaati hakikat dari norma dan hukum, mengembangkan kemampuan sikap positif terhadap makna dan nilai-nilai catatan panjang proklamasi, kemampuan pada upaya Perlindungan dan penegakan Hak Asasi Manusia, juga kemampuan aktualisasi kemerdekaan mengemukakan pendapat di era saat ini. Keempat hal tersebut dirasa bahwasanya Siswa Sekolah Dasar sudah menyadari dnegan baik pentingnya mereaktualisasikan kemampuan berbangsa dan bernegara dalam kehidupan sehari-hari.

Dengan demikian, setelah siswa mengikuti Pendidikan Kewarganegaraan dengan baik dan benar diharapkan mereka akan menjadi warga negara Indonesia yang memiliki kemampuan untuk melakukan perubahan di tengah masyarakat melakukan transfer of learning (proses pembelajaran), transfer of values (proses pengejawantahan nilai-nilai) dan transfer of principles (proses pengalihan prinsip-prinsip) demokrasi, HAM dan masyarakat madani dalam kehidupan nyata(Ubaedillah A \& R, 2008).

\section{KESIMPULAN}

Pendidikan Kewarganegaraan yang humanis-partisipatoris diharapkan mampu menjadi tempat bagi penyemaian prinsip-prinsip demokrasi yang terintegrasikan dengan nilai-nilai budaya Indonesia yang bersumber dari Pancasila sebagai dasar filosofis bangsa yang diimpikan dapat menjadi unsur utama pembentuk karakter berbangsa dan bernegara di Indonesia (Nasution, 2016). Seluruh aspek kehidupan mulai dari orangtua, masyarakat dan juga tenaga pendidik memiliki peran penting dan harus ikut serta dalam 
528 Urgensi Pendidikan Kewarganegaraan : Reaktualisasi Kapabilitas Berbangsa dan Bernegara pada Siswa Sekolah Dasar-Amala Sundari, Dini Anggraeni Dewi

DOI: https://doi.org/10.31004/edukatif.v3i2.381

menumbuhkan kemampuan berbangsa dan bernegara pada anak-anak. Karena pada hakikatnya reaktualisasi sikap berbangsa dan bernegara harus ditanamkan sedari dini kepada generasi penurus Bangsa Indonesia ini, agar tidak adanya lagi penyimpangan-penyimpangan terhadap nilai-nilai berbangsa dan bernegara kedepannya. Pendidikan Kewarganegaraan dapat menjadi sarana pertemuan beragam nilai dan prinsip yang bersumber dari luar dan pemikiran dan nilai-nilai Indonesia, yang diorientasikan untuk melahirkan sebuah sintesis kreatif yang dibutuhkan oleh Indonesia sebagai sebuah negara demokrasi baru yang bersendikan pada Pancasila. Untuk menjadi sebuah negara yang berdemokrasi, Indonesia dapat seiring dan sejalan dengan koridor penguatan wawasan kebangsaan yang diberikan kepada anak-anak berbasis pada memantik kemampuan berbangsa dan bernegara yang ditanamkan sedari dini (Somantri, 1969).

\section{DAFTAR PUSTAKA}

Akbal, M. (2016). Pendidikan Kewarganegaraan dalam Pembangunan Karakter Bangsa. Gadjah Mada University Press Bekerjasama Dengan LAN RI., 1(1), 485-493.

Badan Litbang dan Diklat Kementrian Agama. (2012). Kesadaran Berbangsa dan Bernegara. Badan Litbang Dan Diklat Kementrian Agama RI. https://balitbangdiklat.kemenag.go.id/berita/kesadaranberbangsadanbernegara.

Davidson, S. (2008). Hak Asasi Manusia. Pustaka Utama Grafiti.

Effendi, A. M. (2006). Perkembangan Dimensi Hak Asasi Manusia (HAM) ), dan Proses Dinamika Penyusunan Hukum Hak Asasi Manusia (HAKHAM). Ghalia Indonesia.

El-Muthy, M. (2005). Hak Asasi Manusia dan Konstitusi Indonesia. Kencana Predia Media Grup.

Nasution, A. R. (2016). Urgensi Pendidikan Kewarganegaraan sebagai Pendidikan Karakter Bangsa Indonesia melalui Demokrasi, HAM dan Masyarakat Madani. Jupiis: Jurnal Pendidikan Ilmu-Ilmu Sosial, 8(2), 201-212. https://doi.org/10.24114/jupiis.v8i2.5167

NCCS. (1998). In Search of a Scope and Sequence for Social Studies dalam Social Education (pp. 249-264).

NCSS. (n.d.). Charting A Course: Social Studies for the 21 st Century. NationalCommission on Social Studies in the Schools.

Nurdiman, A. (2009). Pendidikan Kewarganegaraan Kecakapan Berbangsa dan Bernegara (B. Susilawati (ed.)). Pusat Perbukuan, Departemen Pendidikan Nasional.

Rahayu, M., Farida, R., \& Apriana, A. (2019). Kesadaran Bela Negara Pada Mahasiswa. Epigram, 16(2), 175-180. https://doi.org/10.32722/epi.v16i2.2232

Soemantri, S. (1969). Demokrasi Pancasila dan Implementasinya Menurut UUD 1945. Alumni.

Somantri, N. (1969). Pelajaran Kewargaan Negara di Sekolah. IKIP Bandung.

Tilaar, H. A. . (2002). Perubahan Sosial dan Pendidikan: Pengantar Pedagogi Transformatif untuk Indonesia. PT. Gramedia Widiasarana Indonesia.

Ubaedillah A, \& R, A. (2008). Pendidikan Kewarganegaraan, Demokrasi , Hak Asasi Manusia dan Masyarakat Madani. Indonesian Center for Civic Education (ICCE), 10.

Winarno, D. (2006). Paradigma Baru Pendidikan Kewarganegaraan. Bumi Aksara.

Winataputra, U. S. (2003). Pendidikan Kewarganegaraan Sebagai Psiko-pedagogis Untuk Mewujudkan Masyarakat Madani. Dirjen Dikti Depdiknas.

Winataputra, U. S. (2008). Multi Kulturalisme-Bhineka Tunggal Ika dalam Perspektif Pkn Sebagai Wahana Pembangunan Karakter Bangsa Indonesia dalam “Acta Civicus.” Pendidikan Kewarganegaraan, 2, 1. 